\title{
Is ecosystem size more important than locality in determining the environmental characteristics of temporary ponds?
}

\author{
Cecilia Ballón ${ }^{1}$, Núria Àvila ${ }^{1}$, Dani Boix ${ }^{1}$, Rocío López-Flores ${ }^{3}$, Susana Romo ${ }^{4}$, Jordi Sala ${ }^{1}$, \\ Xavier D. Quintana ${ }^{1}$ and Stéphanie Gascón ${ }^{1, *}$
}

${ }^{1}$ GRECO, Institut d'Ecologia Aquàtica, Facultat de Ciències, Universitat de Girona, Av. Ma Aurèlia Capmany, 69, 17071 Girona, España.

2 Área de Ecología, Departamento de Ciencias Agrarias y del Medio Natural, Escuela Politécnica Superior de Huesca, Instituto de Investigación en Ciencias Ambientales (IUCA), Universidad de Zaragoza, Carretera de Cuarte s/n, 22071 Huesca, España.

${ }^{3}$ Departamento de Ecología, Facultad de Biología, Universidad de Valencia, Campus de Burjasot, 46100Burjasot, Valencia, España.

* Corresponding author: stephanie.gascon@udg.edu

Received: 03/02/2014

Accepted: 10/08/2015

\begin{abstract}
Is ecosystem size more important than locality in determining the environmental characteristics of temporary ponds?

Ecosystem size plays a key role in determining ecosystem functioning, affecting community stability and structure at both trophic and taxonomic levels. However, less is known about the influence of ecosystem size on environmental characteristics; for example, do larger ecosystems have higher nutrient availability? The nature of this relationship is important for gaining a better understanding of whether the effects of ecosystem size on community functioning are direct or indirect. Indirect effects may exist when the environmental characteristics of larger ecosystems are different from those of smaller ones, and thus the different functioning of communities observed along the ecosystem-size gradient may respond to, for instance, different levels of nutrient availability, and not uniquely to different ecosystem sizes. Here, we tested whether the environmental characteristics (i.e., the physical, chemical and biological characteristics) of temporary ponds of various sizes differed. We chose temporary ponds because they are abiotic controlled systems in which abiotic factors have a strong influence on aquatic communities. However, temporary ponds are usually spatially clustered; consequently, pond locality might also be important in determining the environmental characteristics of a pond (i.e., ponds close to one another may share similar features). We therefore examined whether pond locality is a more important factor than size in determining the environmental characteristics of a pond. To do so, we sampled environmental characteristics (chlorophyll- $a$, nutrient concentrations, macrophyte biomass, water temperature, conductivity, $\mathrm{pH}$, dissolved oxygen, and total organic and inorganic carbon) of ponds in 5 different localities. A cluster of ponds (10 to 12) was sampled in each locality. Ponds encompassing a wide range of sizes were selected for sampling within each locality. We also performed a meta-analysis (including data from 27 temporary pond localities) to investigate whether the environmental characteristics of the ponds sampled in this study were representative of Mediterranean temporary ponds, and thus if such characteristics could be used to distinguish between Mediterranean temporary ponds from temporary ponds located outside of the Mediterranean region. Our results showed that locality had a strong effect on the environmental characteristics of temporary ponds, whereas size had only a weak influence; only chlorophyll- $a$ and pond depth showed a robust relationship with size, as both increased with pond size independently of locality. Moreover, our results suggest that the typology of the temporary pond (i.e., if they were mountain temporary ponds, salt marsh ponds or lowland ponds) had a larger influence on several environmental characteristics than did regional location (i.e., Mediterranean).
\end{abstract}

Key words: Temporary ponds, physical and chemical parameters, pond size, Mediterranean.

\section{RESUMEN}

¿Es el tamaño del sistema más importante que la localidad para las características ambientales de las lagunas temporales?

El tamaño de los sistemas juega un papel clave en el funcionamiento de los mismos, afectando la estabilidad de las comunidades y su estructura, tanto a nivel funcional como taxonómico. Sin embargo poco se conoce de la relación del 
tamaño del sistema sobre las características ambientales. Por ejemplo, ¿tienen los ecosistemas de mayor tamaño una mayor disponibilidad de nutrientes? Esta relación es relevante para entender si el efecto del tamaño es directo o indirecto. Efectos indirectos se dan si ecosistemas de mayor tamaño presentan características ambientales distintas a los de menor tamaño. En ese caso, las diferencias observadas en el funcionamiento de las comunidades a lo largo del gradiente de tamaños podrían responder, por ejemplo, a distinta disponibilidad de nutrientes, y no únicamente a la diferencia de tamaño de los sistemas. En este estudio se analiza si lagunas temporales de distinto tamaño tienen distintas características ambientales. Sin embargo, las lagunas temporales suelen encontrarse agrupadas, compartiendo unas mismas características locales (p.e. la geología, paisaje, la altitud, microclima, etc.), que pueden también afectar a sus características ambientales. De ahí que sea necesario considerar el efecto localidad. Este estudio analiza el efecto del tamaño y el de la localidad, sobre las características ambientales de las lagunas temporales (nutrientes y clorofila-a, biomasa de macrófitos, temperatura del agua, conductividad, pH, oxígeno disuelto, y carbono orgánico e inorgánico total). Para ello, se han considerado 5 sistemas de lagunas temporales. En cada sistema (i.e. localidad) se muestrearon entre 10 y 12 lagunas, seleccionadas para obtener el mayor rango de tamaños posible. Para identificar si las características ambientales de las lagunas estudiadas eran representativas de lagunas temporales mediterráneas y si se podían discriminar de las observadas en lagunas temporales fuera de esta región, se ha realizado un meta-análisis (incluyendo 27 grupos de lagunas temporales). Nuestros resultados indican que la localidad es más determinante que el tamaño por lo que a características ambientales se refiere. Sólo la clorofila-a y la profundidad se relacionaron con el tamaño de manera robusta (mostrando la misma relación independientemente de la localidad). Además, algunas de las características ambientales de las lagunas temporales se ven más influenciadas por la tipología de laguna (es decir, si se encuentran en zonas montañosas, de marisma, o en tierras bajas) que por el hecho de que la laguna se encuentre dentro de la región mediterránea.

Palabras claves: Lagunas temporales, parámetros físicos y químicos, tamaño de la laguna, Mediterráneo.

\section{INTRODUCTION}

The biogeographical theory that there is a positive relationship between ecosystem size and species richness, habitat availability and habitat heterogeneity has generally come to be accepted over the past several decades (Rosenzweig, 1995; Connor \& McCoy, 2000), and some empirical studies carried out in lakes and rivers have already demonstrated such a relationship (e.g. Dodson, 1992; McHugh et al., 2010). Other studies have shown that the relationship between ecosystem size and species richness does not hold for all groups in the same ecosystem (Oertli et al., 2002; Søndergaard et al., 2005). Moreover, ecosystem size influences community trophic structure (Post et al., 2000) and can also affect community stability, which is generally high in smaller ecosystems but is low in larger ones ( $\mathrm{Li}$ $\&$ Stevens, 2010). Therefore, ecosystem size is a key factor in determining ecosystem functioning because it affects community stability and structure at both trophic and taxonomic levels. Most research, however, has focused on the influence of ecosystem size on communities and not on environmental characteristics (i.e., nutrient availability, conductivity, chlorophyll- $a$ content, etc.). To determine whether the effect of size on ecosystem functioning is direct or indirect, it is necessary to test how ecosystem size affects environmental characteristics of the systems. For example, it has been reported that pond size is positively related to hydroperiod length and also to vegetation development and that these factors are important determinants in the seasonal, diurnal and vertical variability of many abiotic factors (Arle, 2002). Thus, larger ecosystems may have different environmental characteristics than smaller ones do. Consequently, changes in ecosystem functioning may be in response to different environmental characteristics, and not simply to effects of different ecosystem size. This type of indirect effect may have particular relevance in systems controlled by abiotic factors, where it is expected that environmental characteristics will have a strong influence on aquatic communities.

Temporary ponds are highly variable systems subjected to strong abiotic control (e.g. Boix et al., 2004; Angeler, 2007). They are highly diverse in origin and functioning, and are distributed around the world, occurring in many 
different regions and climates types (Williams, 2006). One type of climatic region in which they are especially abundant is the Mediterranean, including the Mediterranean basin, California, west South Africa, south-eastern Australia, and central Chile (Grillas et al., 2004). The estimated surface area occupied by temporary ponds situated within the Mediterranean region in Europe is approximately 63932 ha (Ruiz, 2008); these ponds are primarily located in countries that compose the European portion of the Mediterranean basin, which includes Spain, Portugal, France, Italy, Greece and Malta. On the one hand, the Mediterranean climate affects temporary ponds because of the high number of sunshine hours per year that the ponds are exposed to, which has a positive effect on primary producers by allowing for longer vegetative seasons, and also affects the variability of annual phytoplankton biomass (Álvarez-Cobelas et al., 2005; Beklioglu et al., 2007). Moreover, temporary ponds located in a Mediterranean region are exposed to a high degree of environmental variability during the different seasons (Florencio et al., 2009). The question is whether ecosystem size would be a determinant in habitats with high environmental variability; it has been suggested that ecosystem size will be the primary factor shaping aquatic communities in "stable" ecosystems (ecosystems not subjected to frequent or intense disturbances; Post et al., 2000). Unfortunately, field studies examining the influence of ecosystem size in habitats with high environmental variability (such as temporary ponds) are scarce. It is thus difficult to know whether ecosystem size would play as large a role in shaping the communities of temporary ponds as it does in other systems that have a higher degree of environmental stability. Moreover, the occurrence of temporary ponds is usually spatially clustered (higher frequency of ponds in a limited space; e.g. Díaz-Paniagua et al., 2010), and consequently pond locality may explain the role that local characteristics, such as geology, landscape, catchment area, altitude, and microclimate, may play in determining the environmental characteristics of ponds. In fact, several studies have already noted the impor- tance of local effects in shaping both invertebrate communities (e.g. Tavernini et al., 2009; Vanschoenwinkel et al., 2009; Sim et al., 2013) and vertebrate metacommunities (e.g. Beja \& Alcazar, 2003).

In summary, information regarding the influence of locality and pond size on the environmental characteristics of temporary ponds is scarce. Most studies to date have focused on how locality and size influence species richness or trophic structure (e.g. Schriever \& Williams, 2013; O’Neill \& Thorp, 2014). To our knowledge, the present study is the first attempt to analyse how locality and size affects the environmental characteristics of temporary ponds. Three primary questions were analysed: 1) Do temporary ponds within the Mediterranean region have distinct environmental characteristics?; 2) Is locality more important than size in determining the environmental characteristics of temporary ponds?; and 3) What is the influence of size in shaping the environmental characteristics of temporary ponds? To answer the first question, locality effects were analysed at two different geographical scales. At a larger scale, we compared the environmental characteristics of temporary ponds within the Mediterranean region with those of temporary ponds outside the region by using a meta-analysis that encompassed 27 different localities. This allowed us to test whether temporary ponds in the Mediterranean region have distinctive environmental characteristics. At a finer geographical scale, we used the information obtained from 5 localities (with 10 to 12 temporary ponds in each) to investigate whether there were some common features that could be useful in typifying temporary ponds in the Mediterranean region. In terms of the relative influence of locality and pond size, we expected that locality would be more important than pond size in determining the environmental characteristics of temporary ponds (i.e., neighbouring ponds may share similar environmental characteristics and the expected higher environmental variability may preclude a strong effect of ecosystem size). Thus, to confirm this expected pattern, we quantified the relative effects of size and locality on the environmental characteristics 
of the ponds. Finally, we examined whether there was a general trend in the influence of ecosystem size on the environmental characteristics of ponds independent of their locality.

\section{MATERIALS AND METHODS}

\section{Study sites}

\section{Larger scale approach}

A meta-analysis of the environmental characteristics of temporary ponds was carried out to address whether the temporary ponds of the studied localities shared similar environmental characteristics in the Mediterranean region, and therefore whether ponds within the Mediterranean region are distinguishable from ponds observed outside this region. To do so, we collected information about the environmental characteristics of 27 lo- calities from the literature (see Table S1, available at www.limnetica.com) We included different types of temporary ponds, including turloughs and other karstic waterbodies, salt marshes, lowland, athalassohaline, mountain, and floodplain ponds, located within and outside the Mediterranean region. Data from temporary ponds that were highly impacted by anthropogenic activity were discarded (e.g., some temporary ponds listed in Florín et al. [1993]).

\section{Finer scale approach}

The study was carried out in 57 temporary ponds distributed in 5 different localities, all of which are under some form of official protection, within the Mediterranean region (Fig. 1). Of the 5 localities, 3 were in Spain (Albera [AL], Empordà Wetlands Natural Park [EW] and Clots de Guils [GU]), 1 was in Sardinia, Italy (Giara di Gesturi [GG]), and 1 was in the Alentejo and Vicentine

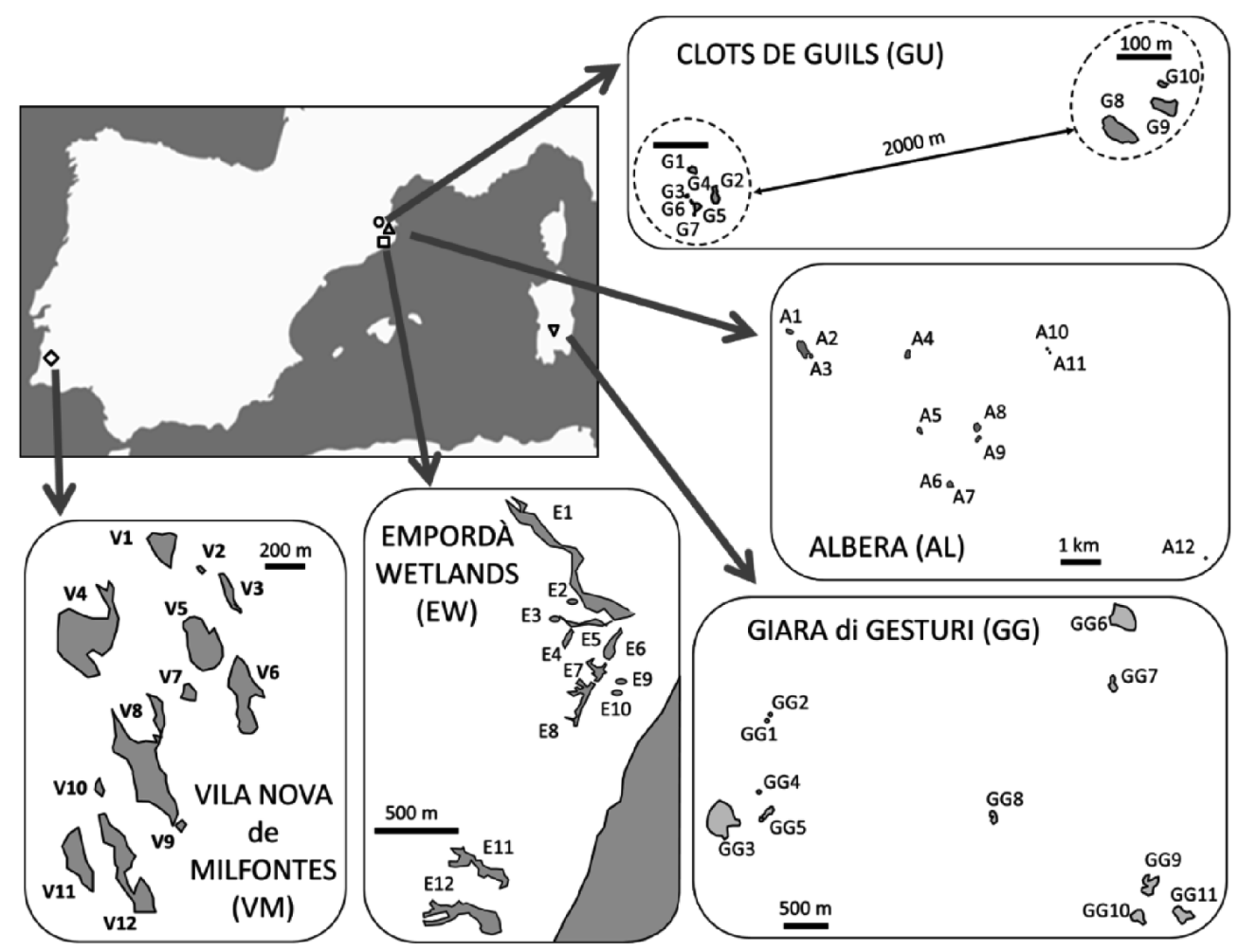

Figure 1. Map of the pond localities included in the study. Solid bars within each locality indicate the scale at which each pond cluster is represented. Mapa de localización de las lagunas de cada localidad incluida en este estudio. La escala de representación de cada localidad aparece en forma de barra. 
Coast Natural Park in southwest Portugal (Vila Nova de Milfontes [VM]). Although all of the pond localities were within the Mediterranean region, they were exposed to a variety of different local features (e.g., low or high altitude, with and without sea influence, etc.; Table 1). We sampled 10-12 ponds representing the widest range of available sizes in each locality.

\section{Sampling and sample processing}

\section{Larger scale}

The environmental variables included in the meta-analysis were those most frequently mentioned in the literature (conductivity, water depth, $\mathrm{pH}$, nitrate and chlorophyll- $a$ concentration), which facilitated comparisons between many different temporary pond localities. We used mean values, as they are the values most often reported in the literature; in instances where the mean was not available but more than one value was available, we calculated the mean as a value between the minimum and the maximum values listed.

\section{Finer scale}

Pond sampling was conducted from February 2012 to June 2012, and in April 2013. The sampling protocol called for sampling to be carried out when water levels in the ponds were relatively high (i.e., at least after 2 months from filling) - measured as the ratio between observed surface and maximum estimated surface (Table 1) - but not during periods of flooding (when water characteristics would be more related to the water source) and desiccation (in which environmental characteristics could dramatically change in just a few days). The maximum surface of the ponds was first estimated using the Google Maps Area Calculator Tool (http://www.daftlogic.com/projects-google maps-area-calculator-tool.htm), and then checked in situ by directly measuring the observed surface. Each pond was sampled once. We measured physical and chemical variables (temperature, dissolved oxygen, conductivity, $\mathrm{pH}$, dissolved inorganic nutrients, total nutrients, total organic and inorganic carbon, fulvic acids and turbidity) of the pond water, and macrophyte biomass and planktonic chlorophyll- $a$ content, as well as general information regarding the condition of the pond habitat. Water temperature, dissolved oxygen, conductivity, $\mathrm{pH}$ (model HACH HQ30d) and water-column depth were measured in situ. Filtered and unfiltered water samples (both $250 \mathrm{ml}$ ) were collected and frozen immediately. Values for dissolved inorganic nutrients (ammonia, nitrite, nitrate and phosphate) were ascertained from the filtered water samples, whereas values for total nutrients (total nitrogen $[\mathrm{N}]$ and phosphorus [P]) were obtained from the unfiltered water samples, following the procedure described in Grasshoff et al. (1983), as were values for total organic carbon. A nutrient limitation indicator was assessed using the ratio between dissolved inorganic nitrogen (DIN) and total $\mathrm{P}$ (where values below 2 indicated $\mathrm{N}$ limitation, and values above 5 indicated $\mathrm{P}$ limitation; Ptacnik et al., 2010). Absorbance at $440 \mathrm{~nm}$ was also measured as a proxy for turbidity. Planktonic chlorophyll- $a$ content was extracted using $90 \%$ acetone, after filtering water samples through Whatman GF/F filters. Chlorophyll- $a$ analyses were carried out using high-pressure liquid chromatography (HPLC; a Waters Pump 1500 Series coupled with a Waters 717 Plus autosampler injector) and a Waters PDA 2996 diode-array detector using an adaptation of the method described by Zapata et al. (2000), with a $\mathrm{C} 8$ reverse phase column and a pyridine mobile phase). To determine the content of fulvic acids, a modification of the method described by Hautala et al. (2000) was used. Samples were acidified to $\mathrm{pH}<2.5$ with $\mathrm{HCl} 1 \mathrm{~N}$. Twenty-four hours following acidification, samples were filtered through a Whatman GF/C filter to eliminate the humic acid precipitates. Fulvic acid concentrations were obtained via spectrophotometry at $350 \mathrm{~nm}$ using a UV-1600PC Spectrometer (Model VVVR) and applying the regression described in Gan et al. (2007). Finally, macrophyte biomass $\left(\mathrm{g} / \mathrm{m}^{2}\right)$ was estimated from the dominant vegetation as the mean dry weight of three replicates of $50.26 \mathrm{~cm}^{2}$ that were collected at random from each pond; dry weight was measured after 
Table 1. Mean and coefficient of variation (\%), in brackets, of the environmental characteristics measured in each locality. Media $y$ coeficiente de variación (\%), entre paréntesis, de las características ambientales medidas en cada localidad.

\begin{tabular}{|c|c|c|c|c|c|}
\hline Variable & $\begin{array}{l}\text { ALBERA } \\
\text { (AL) }\end{array}$ & $\begin{array}{l}\text { GIARA di } \\
\text { GESTURI } \\
\quad(\mathrm{GG})\end{array}$ & $\begin{array}{c}\text { EMPORDÀ } \\
\text { WETLANDS } \\
(\text { EW })\end{array}$ & $\begin{array}{l}\text { GUILS de } \\
\text { CERDANYA } \\
(\mathrm{GU})\end{array}$ & $\begin{array}{c}\text { VILA NOVA } \\
\text { de MILFONTES } \\
\text { (VM) }\end{array}$ \\
\hline Country & Spain & Italy & Spain & Spain & Portugal \\
\hline Temporary pond type & lowland & lowland & salt marshes & mountain & lowland \\
\hline \multirow{2}{*}{ Geographical coordinates } & $42^{\circ} 22^{\prime} \mathrm{N}$ & $39^{\circ} 45^{\prime} \mathrm{N}$ & $42^{\circ} 13^{\prime} \mathrm{N}$ & $42^{\circ} 28^{\prime} \mathrm{N}$ & $37^{\circ} 45^{\prime} \mathrm{N}$ \\
\hline & $2^{\circ} 57^{\prime} \mathrm{E}$ & $8^{\circ} 58^{\prime} \mathrm{E}$ & $3^{\circ} 06^{\prime} \mathrm{E}$ & $1^{\circ} 49^{\prime} \mathrm{E}$ & $8^{\circ} 47^{\prime} \mathrm{W}$ \\
\hline Sampling date & Feb-Mar 2012 & Apr-12 & Apr-May 2012 & Jun-12 & Apr-13 \\
\hline Altitude (m) & 200 & 600 & 0 & 2100 & 55 \\
\hline Number of ponds & 12 & 11 & 12 & 10 & 12 \\
\hline Habitat condition (ECELS) & $92.17(9)$ & $89.46(4)$ & $86.83(10)$ & $92.40(3)$ & $97.75(5)$ \\
\hline Maximum surface $\left(\mathrm{m}^{2}\right)$ & $14972(106)$ & $20171(130)$ & $11559(155)$ & 717 (109) & $17132(136)$ \\
\hline Water column depth $(\mathrm{cm})$ & $94(71)$ & $26(48)$ & $69(90)$ & $34(70)$ & $62(43)$ \\
\hline Dissolved oxygen $(\mathrm{mg} / \mathrm{L})$ & $8.5(26)$ & $10.6(14)$ & $7.3(37)$ & $6.4(27)$ & $4.6(26)$ \\
\hline Conductivity $(\mu \mathrm{S} / \mathrm{cm})$ & $251(69)$ & $420(26)$ & $26955(81)$ & $28(60)$ & $746(37)$ \\
\hline $\mathrm{pH}$ & $7.5(6)$ & $9.5(10)$ & $8.8(3)$ & $6.5(12)$ & $6.5(6)$ \\
\hline Temperature $\left({ }^{\circ} \mathrm{C}\right)$ & $12.5(16)$ & $18.2(25)$ & $18.9(7)$ & $21.2(30)$ & $21.5(8)$ \\
\hline $\mathrm{PO}_{4}^{3-}(\mathrm{mg} \mathrm{P} / \mathrm{L})$ & $0.006(79)$ & $0.001(59)$ & $0.010(130)$ & $0.003(42)$ & $0.016(160)$ \\
\hline $\mathrm{TP}-\mathrm{P}(\mathrm{mg} \mathrm{P} / \mathrm{L})$ & $0.061(35)$ & $0.095(81)$ & $0.141(70)$ & $0.068(53)$ & $0.126(132)$ \\
\hline TN-N (mg N/L) & $1.717(25)$ & $1.137(31)$ & $1.942(38)$ & $0.990(42)$ & $2.771(20)$ \\
\hline$\overline{\mathrm{DIN}}(\mathrm{mg} \mathrm{N} / \mathrm{L})$ & $0.047(81)$ & $0.039(63)$ & $0.065(73)$ & $0.061(57)$ & $0.024(87)$ \\
\hline DIN:TP & $1.64(63)$ & $1.18(61)$ & $1.35(83)$ & $2.92(105)$ & $0.68(91)$ \\
\hline TIC (mg C/L) & $14.67(95)$ & $8.67(29)$ & $62.11(35)$ & $2.42(91)$ & $14.30(137)$ \\
\hline TOC (mg C/L) & $24.93(21)$ & $12.55(27)$ & $22.98(36)$ & $14.83(41)$ & $57.67(19)$ \\
\hline Absorbance $440 \mathrm{~nm}$ & $0.040(34)$ & $0.028(66)$ & $0.041(76)$ & $0.029(71)$ & $0.150(25)$ \\
\hline Fulvic acids (mg FA/L) & $9.35(32)$ & $2.48(40)$ & $4.55(46)$ & $5.23(58)$ & $35.56(24)$ \\
\hline Planktonic chlorophyll- $a(\mu \mathrm{g} / \mathrm{L})$ & $9.91(101)$ & $4.88(102)$ & $12.03(93)$ & $4.10(102)$ & $10.47(142)$ \\
\hline Macrophyte biomass $\left(\mathrm{g} / \mathrm{m}^{2}\right)$ & $600(65)$ & $80(48)$ & $20(260)$ & $100(108)$ & $1920(35)$ \\
\hline \multicolumn{6}{|c|}{ Vegetation in the water column (number of ponds) } \\
\hline Absence & 0 & 0 & 3 & 0 & 0 \\
\hline Only in the deepest part & 0 & 0 & 1 & 0 & 0 \\
\hline From deepest part to $75 \%$ of water column & 2 & 0 & 4 & 0 & 0 \\
\hline Occupying the whole water column & 10 & 11 & 4 & 10 & 12 \\
\hline \multicolumn{6}{|l|}{ Vegetation cover (number of ponds) } \\
\hline Absence & 0 & 0 & 1 & 0 & 0 \\
\hline Less than $25 \%$ & 0 & 0 & 6 & 1 & 0 \\
\hline From 25 to $75 \%$ & 0 & 0 & 3 & 3 & 0 \\
\hline More than $75 \%$ & 12 & 11 & 2 & 6 & 12 \\
\hline
\end{tabular}


oven-drying the material at $60{ }^{\circ} \mathrm{C}$ for $48 \mathrm{~h}$. We used a rapid assessment method originally developed for Mediterranean shallow lentic ecosystems (ECELS index; Sala et al., 2004) to evaluate habitat condition, with values ranging from 0 (low habitat quality) to 100 (high habitat quality).

\section{Statistical analyses}

\section{Larger scale}

We calculated Bray-Curtis dissimilarity among the metadata for use as the resemblance measure in non-parametric multidimensional scaling MDS and ANOSIM analyses. One-way ANOSIM was used to test the degree of similarity in environmental characteristics between temporary ponds within the Mediterranean region and those outside this region (the "region" factor had 3 levels: Mediterranean, non-Mediterranean, and a level exclusively formed by the localities of our study, to test their similarity to both Mediterranean and non-Mediterranean ponds). A second one-way ANOSIM was carried out to examine whether different types of temporary ponds had different environmental characteristics ("type" factor had 6 levels: turloughs and related waterbodies, salt marshes, lowland, athalassohaline, mountain, and floodplain ponds). Although this type of test is similar to a standard univariate ANOVA, it operates on a resemblance matrix and does not require either normality or variance homogeneity, with results expressed as a global $\mathrm{R}$ value that oscillates between -1 and +1 , and a $p$-value. Negative $R$ values may occur when variability is higher within the level of the factor than among them (Chapman \& Underwood, 1999). When R is 0 or close to 0 , similarities within each level and among levels are considered to be equivalent (i.e., no factor effect). In contrast, high and positive $R$ values indicate that samples within the same level resemble each other more so than to samples from other levels (Clarke \& Gorley, 2001).

\section{Finer scale}

A Principal Component Analysis (PCA) was used to summarize the general data variability considering all localities together. The variables included in the PCA were conductivity (Cond), $\mathrm{pH}$, temperature ( $\mathrm{T})$, water column depth (depth), dissolved oxygen $\left(\mathrm{O}_{2}\right)$, DIN, phosphate $\left(\mathrm{PO}_{4}^{3-}\right)$, total phosphorus (TP), total nitrogen (TN), total organic carbon (TOC), total inorganic carbon (TIC), nutrient limitation (DIN:TP), percentage of fulvic acid (fulvic acid), turbidity, planktonic chlorophyll-a (Chl- $a$ ), macrophyte biomass (macrophyte DW) and habitat condition (ECELS). All variables were normalized prior to application of the PCA.

The ANOSIM was carried out to explore whether the different localities exhibited similar environmental characteristics. The chosen option was the one-way layout ("locality" as the factor, with 5 levels: AL, EW, GU, GG and VM). Additionally, a PERMDISP analysis was used to test whether the different localities displayed similar patterns of environmental variability. PERMDISP, a dissimilarity-based multivariate extension of Levene's test, is used to test the homogeneity of multivariate dispersions on the basis of any resemblance measure (Anderson et al., 2008). We used Euclidean distance for both the ANOSIM and PERMDISP applications. In addition, hierarchical partitioning analyses were carried out to quantify the influence of locality and pond size independently on environmental characteristics (PCA scores of the 5 PCA axes extracted were used as response variables, with "locality" and "size" set as the explanatory variables).

Analyses of Covariance (ANCOVA) were performed to test general responses of the environmental variables against pond size. Thus, the interaction between pond size and locality will inform whether the relationship between pond size and a given environmental variable is the same for all localities. A significant interaction between locality and pond size would indicate that the influence of size is locally dependent because it would show that in at least one of the localities the relationship between the environmental variable and pond size is different than in the others. In contrast, the lack of a significant interaction between locality and pond size may indicate a locally independent relationship, as a similar relationship will be obtained regardless 
of the locality. Furthermore, for locally independent relationships, 3 different trends might exist: 1) no significant relationship with pond size (no pond size effect) but significant differences among localities (locality effect); 2) a significant relationship with pond size (pond size effect), but no significant differences among localities (no locality effect); and 3) a significant relationship with both pond size (pond size effect) and significant differences among localities (locality effect). The first trend would correspond to a pure locality effect (i.e., pond size is not significant), the second would correspond to a pure size effect (i.e., locality is not significant), and the third trend would correspond to shared effects (i.e., both pond locality and size are significant).

PCA, ANOSIM (with 999 permutations in all cases), PERMDISP and MDS were carried out using PRIMER v6+ software (Clarke \& Gorley,
2006). Hierarchical partitioning analyses were performed using the "hiert.part" package (Walsh \& Mac Nally, 2013) and ANCOVA was performed using the "lm" function, both of which are written in $\mathrm{R}$ language ( $\mathrm{R}$ Development Core Team, 2015).

\section{RESULTS}

\section{Environmental characteristics of temporary ponds}

The environmental characteristics found in the studied localities were within the range of those reported for other temporary ponds (Fig. 2; Table S1). The meta-analysis showed that, at a larger geographical scale, temporary ponds had similar environmental features regardless of the

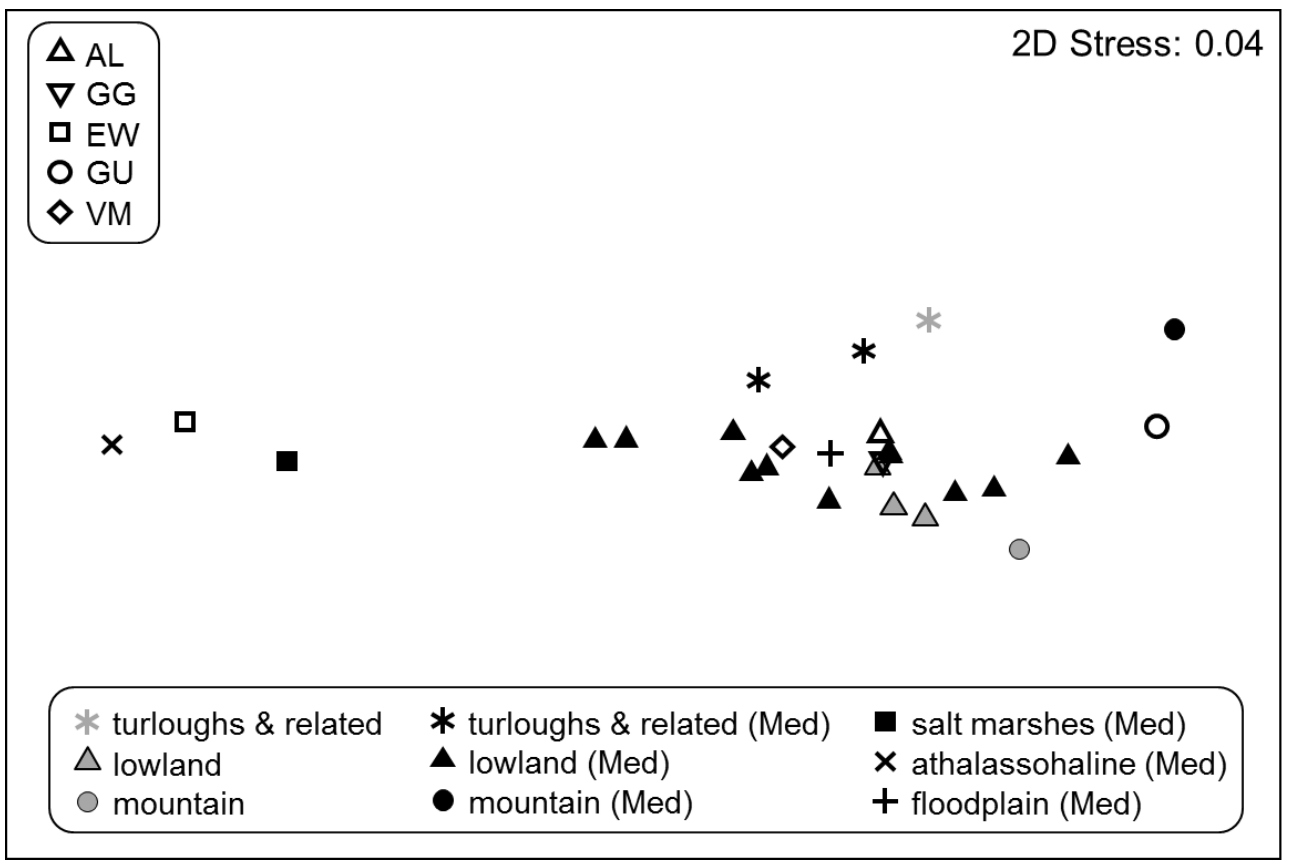

Figure 2. Non-parametric multidimensional scaling plot showing the resemblance on selected environmental characteristics (BrayCurtis dissimilarity) among several temporary pond types. Each point corresponded to a locality composed of a pond cluster (several ponds). The MDS was constructed using the mean value between the minimum and the maximum for each of the following environmental characteristics: conductivity, water depth, $\mathrm{pH}$, nitrate and chlorophyll- $a$ concentration. See Table S1 for details on the references used for this meta-analysis. Representación no paramétrica multidimensional (MDS) de la similitud de las características ambientales seleccionadas (distancia de Bray-Curtis) entre los distintos tipos de lagunas temporales. Cada punto corresponde a una localidad formada por un grupo de lagunas. El MDS se construyó usando el valor medio entre el mínimo y el máximo para cada una de las siguientes características ambientales: Conductividad, profundidad de la columna de agua, pH, concentración de nitrato y clorofila-a. Ver Tabla S1 para más detalles sobre los estudios incluidos en este meta-análisis. 
region in which they were located (ANOSIM by region; Global $R=-0.038, p=0.563$ ). In contrast, significant differences arose when the influence of the type of temporary pond was analysed (ANOSIM by type; Global $R=0.588$, $p=0.001$ ), primarily a result of the differences between lowland and mountain temporary ponds (Pairwise Tests, $p=0.002$ ), and lowland and salt marsh temporary ponds (Pairwise Tests; $p=0.006$ ). In fact, both mountain ponds and salt marsh ponds showed extreme positions in the MDS plot (Fig. 2), indicating a higher dissimilarity between these types of ponds and the other temporary pond types. Thus, a greater resemblance is observed within the same temporary pond typology than among ponds within the same region (e.g., EW and salt marshes, or GU and mountain ponds; Fig. 2).

At a finer geographical scale, the ponds in the studied localities had similar surface areas, with the exception of the mountain locality (GU), in which ponds were generally smaller. All studied temporary ponds had good to high habitat condition (ECELS values above 70; Table 1), and macrophyte cover and vertical structure was high in almost all localities, with the exception of salt marshes (EW), where a number of ponds with poor macrophyte vegetation were identified. The lowest values for conductivity were found in ponds in the mountain locality (GU), whereas ponds in the salt marsh locality showed the highest conductivity values, with ponds in the lowland localities having intermediate values. All localities except 2 mountain ponds (GU9 and GU7) were $\mathrm{N}$ limited. Two localities, one in the lowlands (GG) and one in the mountains (GU), had shallow ponds, with a mean water-column depth below $40 \mathrm{~cm}$, whereas ponds in the other localities had a mean water-column depth above 60 $\mathrm{cm}$, with AL being the locality with the deep-

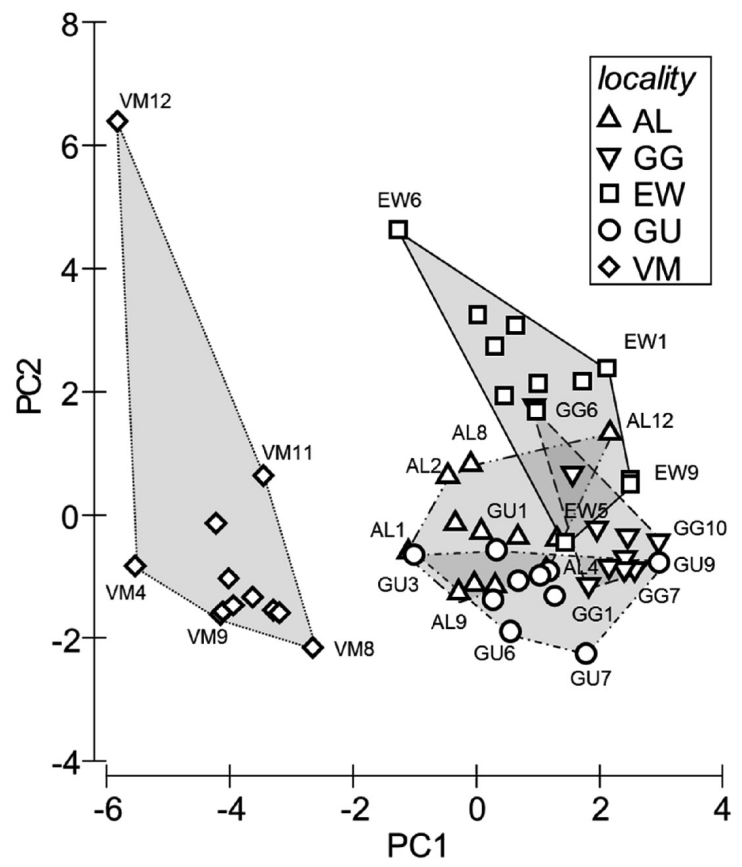

Figure 3. PCA plot for the first two axes extracted. The left plot informs about the relationships among the variables and includes a circle of correlations. The closer a variable is to the circle, the better we can reconstruct this variable from the first two axes (and the more important is to interpret these axes). The right plot depicts sample positions; samples collected from the same locality are sited within the same polygon. Gráfico de PCA mostrando los dos primeros ejes extraídos. El gráfico izquierdo informa de la relación entre variables, incluye además el círculo de correlaciones. Cuando más cerca se encuentra una variable del círculo, mejor relación tiene esa variable con los dos ejes, y más importante es para interpretar los ejes. El gráfico derecho muestra la posición de las muestras (lagunas). Las muestras de una misma localidad se encuentran dentro de un mismo polígono. 
est ponds. The lowland ponds located in VM and the mountain ponds (GU) had the lowest mean values of $\mathrm{pH}$; however, VM ponds also had the lowest values of dissolved oxygen and DIN, and had the highest values for phosphate, TN, TOC, fulvic acids, macrophyte biomass and turbidity (Table 1). The highest concentration of planktonic chlorophyll- $a$ was found in the salt marsh locality (EW), coinciding with the lower macrophyte biomass and higher TP content. The observed coefficients of variation indicate a high level of environmental variability within each locality, mainly due to disparities in nutrient content, planktonic chlorophyll- $a$ and macrophyte biomass (Table 1). Moreover, PERMDISP results indicated that all localities had similar environmental variability $\left(F_{4,52}=2.7206 ; p=0.127\right)$.

The results of the PCA revealed the existence of a high level of heterogeneity in the environmental conditions among the temporary ponds (the axis that summarized greater variability, the first one, only explained $33 \%$ of the total variability observed; Table 2). The first PCA (Fig. 3) was positively correlated with dissolved oxygen and $\mathrm{pH}$, and negatively correlated with TOC, TN, turbidity, fulvic acids and macrophyte biomass (Table 2). This axis mainly distinguished the VM samples (negative coordinates) from the other localities (positive coordinates); thus, VM samples displayed lower dissolved oxygen and $\mathrm{pH}$ but higher TOC, TN, turbidity, fulvic acids and macrophyte biomass than did the rest of the localities (Fig. 3). The second PCA axis grouped $18 \%$ of the variability and was positively correlated with $\mathrm{TP}, \mathrm{PO}_{4}^{3-}$, TIC and planktonic Chl$a$ and negatively correlated with habitat condition (ECELS). Samples from GU and VM had lower values for this axis, showing lower TP, $\mathrm{PO}_{4}^{3-}$, TIC and planktonic Chl- $a$ but higher habitat condition than EW samples (with higher values for the second PCA axis). Samples from AL and GG were placed in an intermediate position (Fig. 3). The third PCA axis grouped $10 \%$ of the variability and was positively correlated with DIN and P limitation (given that higher values of DIN:TP suggest P limitation). The fourth axis grouped $9 \%$ of the variability and was negatively correlated with conductivity, temperature and TIC. Finally, the fifth PCA axis (explaining $7 \%$ of the variability) was positively correlated

Table 2. Pearson correlation coefficients between variables and PCA axes. Significant relationships after Holm's adjustment are shown in bold. The explained variation (\%) for each PCA axis is shown in italics. Coeficientes de correlación de Pearson entre las variables y los ejes del PCA. En negrita las relaciones significativas aplicando el ajuste de Holm. La varianza explicada (\%) de cada eje del PCA se muestra en cursiva.

\begin{tabular}{rccccc}
\hline & PCA1 & PCA2 & PCA3 & PCA4 & PCA5 \\
\hline Water column depth & -0.2092 & 0.137 & 0.4053 & 0.1327 & $\mathbf{- 0 . 7 1 0 7}$ \\
Dissolved oxygen & $\mathbf{0 . 7 1 5 3}$ & -0.0402 & -0.3952 & 0.0837 & 0.0969 \\
Conductivity & 0.232 & 0.4202 & -0.2149 & $\mathbf{- 0 . 6 2 1 5}$ & 0.0402 \\
pH & $\mathbf{0 . 6 7 2 5}$ & 0.2472 & -0.3533 & -0.2333 & -0.1718 \\
Temperature & -0.161 & -0.1904 & 0.1219 & $\mathbf{- 0 . 4 9 6 7}$ & 0.4263 \\
ECELS & -0.3238 & $\mathbf{- 0 . 6 4 5 5}$ & 0.0523 & -0.2525 & -0.0824 \\
DIN & 0.2499 & 0.3839 & $\mathbf{0 . 7 6 4 2}$ & -0.146 & 0.0947 \\
PO $3-$ & -0.3829 & $\mathbf{0 . 5 9 6 1}$ & -0.0053 & 0.1981 & $\mathbf{0 . 4 7 7 5}$ \\
TIC & 0.0583 & $\mathbf{0 . 6 6 7 9}$ & 0.0007 & $-\mathbf{0 . 5 1 6 7}$ & -0.3261 \\
TOC & $\mathbf{- 0 . 9 3 0 7}$ & 0.016 & -0.1024 & -0.2203 & -0.0209 \\
TN & $\mathbf{- 0 . 7 9 3 7}$ & 0.3254 & -0.086 & -0.2905 & -0.1554 \\
TP & -0.3171 & $\mathbf{0 . 7 9 4 8}$ & 0.0155 & 0.2058 & 0.2976 \\
Absorbance 440 & $\mathbf{- 0 . 9 3 5 8}$ & 0.0568 & -0.0518 & -0.0614 & 0.0602 \\
Fulvic acids & $\mathbf{- 0 . 8 5 9 7}$ & -0.2819 & 0.0372 & 0.0833 & 0.0248 \\
Macrophyte biomass & $\mathbf{- 0 . 8 4 0 2}$ & -0.2682 & -0.0686 & -0.0738 & -0.0248 \\
Planktonic chlorophyll- $a$ & -0.2803 & $\mathbf{0 . 6 1 3 3}$ & 0.0589 & 0.3892 & -0.1628 \\
DIN:TP & 0.3655 & -0.1939 & $\mathbf{0 . 7 6 9 4}$ & -0.1744 & 0.1935 \\
& 33 & 18 & 10 & 9 & 7
\end{tabular}


with $\mathrm{PO}_{4}^{3-}$ but negatively correlated with watercolumn depth (Table 2).

\section{Locality vs. size effects}

In accordance with the PCA results, ANOSIM comparisons revealed the existence of a locality effect (ANOSIM; Global $R=0.583, p=0.001$ ). Likewise, the hierarchical partitioning analysis showed that local effects had a higher influence on environmental variability than did pond size (Fig. 4). The unique contribution of locality explained more than $70 \%$ of the total variability observed on the 5 PCA axes examined, whereas pond size was only poorly related to environmental variability (see Fig. 4). Moreover, a low proportion of shared variation explained by local and size effects was also found, indicating a low degree of covariation.

\section{Ecosystem size influence}

ANCOVA results also revealed the importance of locality because many of the environmental variables analysed showed pure locality effects (dissolved oxygen, $\mathrm{PO}_{4}^{3-}$, TN, TP, macrophyte biomass, TIC and TC), reinforcing the idea that locality is an important factor in shaping the environmental characteristics of temporary ponds. Conductivity, $\mathrm{pH}$, fulvic acids, temperature, and TOC had a locality dependent relationship with pond size (i.e., a significant interaction between pond size and locality), indicating that the relationship between the environmental variables and pond size was not the same for all localities, and thus there was no general trend of the influence of pond size along those variables. Water-column depth and Chl- $a$ had a locality-independent relationship with pond size (both having a non-significant interaction $[p>0.05]$ between system and pond size). Furthermore, both variables had a significant positive relationship with pond size (water-column depth: $F_{1,47}=15.7317$, $p=0.0002$; Chl- $a: F_{1,47}=5.4634, p=0.0237$ ). Chlorophyll- $a$ showed a pure size effect, with all localities having similar Chl- $a$ concentrations, whereas water-column depth differed among localities $\left(F_{4,47}=8.9096, p<0.0001\right)$, indicating

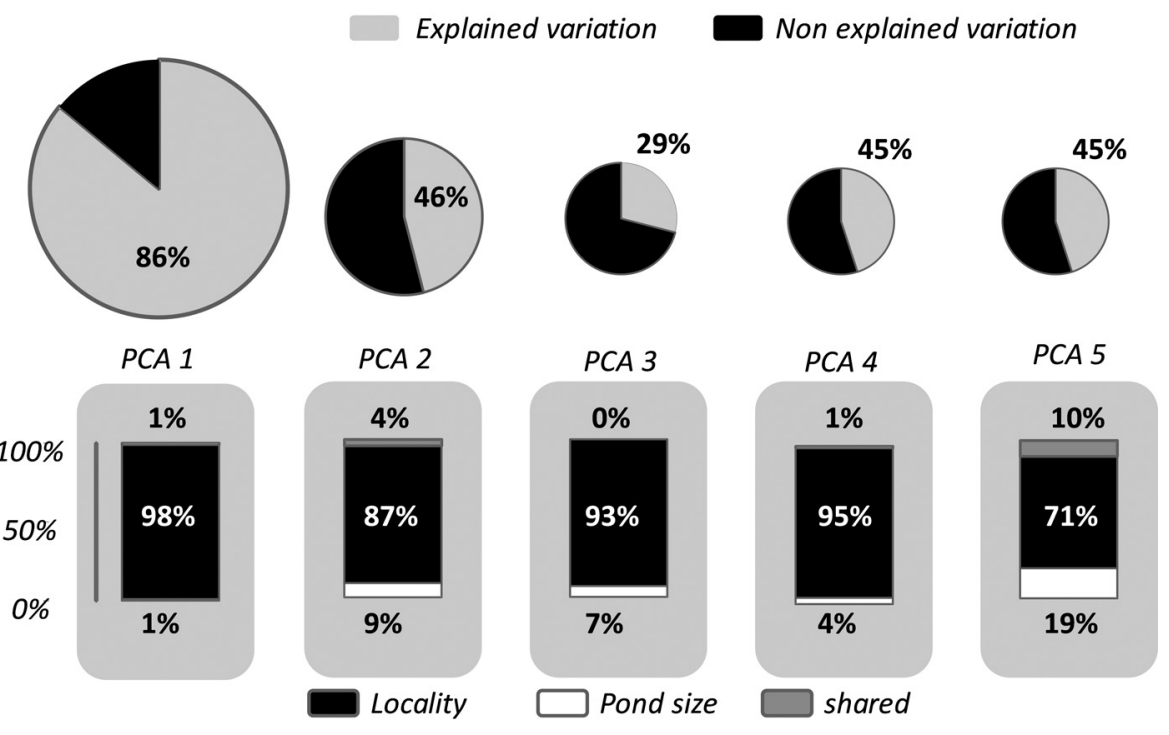

Figure 4. The results of the hierarchical partitioning analyses. Pie charts indicate the explained variability (values in percentage) of the hierarchical approach for each PCA axis. The size of the chart is proportional to the explained variability of each PCA axis. The independent and shared contribution of locality and pond size on the environmental variability is shown as a percentage of the total explained variability in the bar plot. Resultados del análisis de partición jerarquizado. Los diagramas de sectores indican la varianza explicada (valores en porcentaje) del análisis jerárquico para cada eje del PCA. El tamaño del gráfico es proporcional a la varianza explicada por cada eje. Las barras indican la contribución independiente, y compartida, de localidad y tamaño al explicar la variabilidad ambiental (porcentaje del total explicado). 
that both pond size and locality were important (i.e., a shared effect). Finally, turbidity (Abs $440 \mathrm{~nm}$ ) and nutrient limitation (DIN:TP) were not significantly different among the localities and were not correlated with pond size.

\section{DISCUSSION}

\section{Environmental characteristics of temporary ponds}

At a larger geographical scale, our results suggest that the environmental characteristics of temporary ponds included in our analysis were more likely to be determined by the typology of the temporary pond than by being located within the Mediterranean region. Although with the caveat that our meta-analysis included only a relatively small number of studies, our results suggest that, such as high mountain lakes (e.g. Catalán et al., 2006), temporary ponds may share similar environmental features regardless of where they are located. Moreover, the high similarity of our locations with others not included in our study but which encompass ponds of similar typologies, suggests that the ponds included in the finer scale section of our analysis could be considered as representative of different types of temporary ponds (i.e., lowland ponds, salt marshes and mountain ponds). For instance, the salt marsh locality (EW) used in our study showed characteristics similar to the Doñana salt marshes of southern Spain Similarly, our mountain locality showed similar environmental features as other mountain localities from the Mediterranean region (Italy; Table S1) but also from other parts of the world (e.g., Bolivia; Table S1).

At finer geographical scale, the values for habitat condition of the studied ponds indicated that the systems were within the range of good to high habitat condition (ECELS $>70$; Sala et al., 2004). Because all of the localities were within protected areas, they may be subjected to lower levels of anthropogenic pressures, which may explain the high habitat condition of the ponds (Gascón et al., 2012). Although all localities were well preserved, the primary environmental characteristics were different in each locality. For example, VM ponds had more distinct environmental characteristics, which were close to those expected in dystrophic ponds (high concentrations of TOC and humic substances, and macrophyte biomass, combined with low dissolved oxygen and $\mathrm{pH}$ ). Temporary ponds in the EW locality were within a salt marsh and consequently showed the highest conductivity values of our study due to higher salinity levels. Although such dystrophic or coastal characteristics were not observed in the remainder of the localities, they did show other particularities in their environmental features (water column depth, nutrient content, etc.) that may contribute to their differentiation. Thus, it is difficult to identify a unique set of variables that would typify all temporary pond types found within the Mediterranean region. However, an inherent characteristic usually reported for Mediterranean aquatic systems - a high level of environmental variability (Álvarez-Cobelas et al., 2005; Beklioglu et al., 2007) - was also valid for temporary ponds. Moreover, our results also suggest that different pond clusters within the Mediterranean region not only had a high degree of environmental variability but also that the form of variability was similar among them (i.e., there was no significant differences in the variability of the environmental characteristics of ponds among localities).

\section{Locality vs. size effects}

Our results are consistent with those of other studies that have examined local effects in the environmental characteristics of ponds (e.g. Ruhí et al., 2009; Drinan et al., 2013). In fact, local effects were the main factor responsible for the observed differences among systems, as only a weak influence of pond size was detected. At the larger geographical scale, we observed that different temporary pond typologies showed distinct environmental characteristics. Previous studies have reported the existence of environmental differences when comparing different types of temporary waters at finer geographical scales (Hamilton IV et al., 2012). Thus, the strong loca- 
lity effect we observed may be explained by the inclusion of different temporary pond typologies within the Mediterranean region. Therefore, local effects are not only influencing zooplankton (Michels, 2001) and other taxonomic groups (Ruhí et al., 2009) but also the environmental characteristics of ponds. On the other hand, and as was expected, we found that pond size had only a small effect on environmental characteristics. It has been suggested that ecosystem size plays a minor role in determining community functioning in ecosystems that experience a high level of variability due, for example, to intense or frequent perturbations (Post, 2002). Our results indicate that this is also true for the environmental characteristics of temporary ponds.

\section{Ecosystem size influence}

The pond size effect was less determinant than the observed differences among localities, but it did explain some of the variability. In fact, only two environmental variables - water-column depth and Chl- $a$ - showed the same size effect independently of the studied locality, with both showing a positive relationship. The positive relationship between surface area and watercolumn depth is not rare (e.g. Boven et al., 2008), nor was it a surprise, given that bigger ponds or lakes are also usually the deepest ones (e.g. Søndergaard et al., 2005; Hayashi \& van der Kamp, 2007). Therefore, in our studied ponds, the morphometry of a pond - that is, the pond's surface area and depth - could be viewed as a proxy for pond size. Pond morphometry may also influence Chl- $a$ concentration. Thus, the positive relationship between pond size and catchment area (Nõges, 2009), which we also observed (Pearson correlation; $N=57, r=0.62$, $p<0.001$ ), could lead to higher input of nutrients in larger ponds. Increases in nutrient concentrations often lead to increases in phytoplankton biomass (e.g. Romo et al., 2007). However, we did not find higher nutrient availability in the larger ponds, which could have accounted for the Chl- $a$ trend we observed along the pond-size gradient. The increase in Chl- $a$ could therefore be a result of higher recruitment of phytobenthos into the water column due to the strong interactions between phytobenthos and phytoplankton that are known to occur in shallow lakes (Romo et al., 2007; Villena \& Romo, 2007). Moreover, small ponds had a smaller insulated area, as their high perimeter-to-area ratio may facilitate canopy shading (Palik et al., 2001). Thus, it seems plausible to relate the increase of Chl- $a$ in larger ponds to the effects of reduced shade coverage (e.g. Mokany et al., 2008) and higher phytoplankton recruitment from the phytobenthos (Romo et al., 2007; Villena \& Romo, 2007). Nevertheless, additional studies are needed to further investigate what specific mechanisms are responsible for the observed pattern; for example, wind-driven turbulence may be more important in larger ponds, which may in turn influence Chl- $a$ content.

In summary, the present study is the first attempt to establish the importance of ecosystem size and locality effects in determining the environmental characteristics of temporary ponds. Our results showed that pond size had only a weak influence on environmental characteristics in comparison to the locality effect. This information may be of relevance to further studies that focus on the role that ecosystem size plays in determining the aquatic biota of temporary ponds, given that, if a relationship is detected, it would be due primarily to direct processes and not to indirect processes because of the changes in environmental characteristics between small and large temporary ponds. This would be in accordance with the lower importance of ecosystem size that would be expected in highly variable environments (Post et al., 2000). The strong locality effect may be a consequence of the heterogeneity of temporary pond typologies that occurs within the Mediterranean region. Moreover, our results suggest that the typology of temporary ponds (mountain, salt marsh, lowland, karstic, etc.) had a greater influence on the environmental characteristics of the ponds than did their being located within the same region. 


\section{ACKNOWLEDGEMENTS}

We would like to thank the Departamento de Conservação da Natureza e Florestas do Algarve, the Departament d'Agricultura, Ramaderia Pesca, Alimentació i Medi Natural, the Empordà Wetlands Natural Park and the Authorities of the Base Militar General Álvarez de Castro for granting permission to perform our study in the ponds under their management. We also want to thank Simonetta Bagella, Luis Cancela da Fonseca, Maria Carmela Caria, Jordi Compte, Helena Costa, Laura Guirado, Margarida Machado, Albert Ruhí and Lluís Zamora for field assistance. Núria Àvila held a PhD grant from the University of Girona (BR2012/02). This work was supported by the Autonomous Region of Sardinia, Italy-Progetto Paulis (CRP 24943), by the Ministerio de Ciencia y Tecnología of the Spanish Government (CGL2011-23907), and by the Generalitat de Catalunya (2014 SGR 484).

\section{REFERENCES}

\section{* Supplementary references available at www.limnetica.com}

ÁLVAREZ-COBELAS, M., C. ROJO \& D. G. ANGELER. 2005. Mediterranean limnology: current status, gaps and the future. Journal of Limnology, 64: 13-29.

ANDERSON, M. J., R. N. GORLEY \& K. R. CLARKE. 2008. PERMANOVA + for PRIMER: Guide to software and statistical methods. PRIMER-E. Plymouth, UK.

ANGELER, D. G. 2007. Resurrection ecology and global climate change research in freshwater ecosystems. Journal of the North American Benthological Society, 26: 12-22.

ARLE, J. 2002. Physical and chemical dynamics of temporary ponds on a calcareous plateau in Thuringia, Germany. Limnologica-Ecology and Management of Inland Waters, 32: 83-101.

BEJA, P. \& R. ALCAZAR. 2003. Conservation of Mediterranean temporary ponds under agricultural intensification: an evaluation using amphibians. Biological Conservation, 114: 317-326.
BEKLIOGLU, M., S. ROMO, I. KAGALOU, X. D. QUINTANA \& E. BÉCARES. 2007. State of the art in the functioning of shallow Mediterranean lakes: workshop conclusions Hydrobiologia, 584: 317-326.

BOIX, D., J. SALA, X. D. QUINTANA \& R. MORENO-AMICH. 2004. Succession of the animal community in a Mediterranean temporary pond. Journal of the North American Benthological Society, 23: 29-49.

BOVEN, L., B. VANSCHOENWINKEL, E. R. DE ROECK, A. HULSMANS \& L. BRENDONCK. 2008. Diversity and distribution of large branchiopods in Kiskunsag (Hungary) in relation to local habitat and spatial factors: implications for their conservation. Marine and Freshwater Research, 59: 940-950.

CATALÁN, J., L. CAMARERO, M. FELIP, S. PLA, M. VENTURA, T. BUCHACA, F. BARTUMEUS, G. DE MENDOZA, A. MIRÓ, E. O. CASAMAYOR, J. M. MEDINA-SÁNCHEZ, M. BACARDIT, M. ALTUNA, M. BARTRONS \& D. DÍAZ DE QUIJANO. 2006. High mountain lakes: extreme habitats and witnesses of environmental changes. Limnetica, 25: 551-584.

CHAPMAN, M. G. \& A. J. UNDERWOOD. 1999. Ecological patterns in multivariate assemblages: information and interpretation of negative values in ANOSIM tests. Marine Ecology Progress Series, 180: 257-265.

CLARKE, K. R. \& R. N. GORLEY. 2001. PRIMER v5: User Manual and Tutorial. PRIMER-E. Plymouth.

CLARKE, K. R. \& R. N. GORLEY. 2006. PRIMER v6: User Manual/Tutorial. PRIMER-E. Plymouth.

CONNOR, E. F. \& E. D. MCCOY. 2000. The speciesarea relationship. In: Encyclopedia of Biodiversity. (Eds S.A. Levin): pp. 397-411. ACADEMIC PRESS.

DÍAZ-PANIAGUA,C., R. FERNÁNDEZ-ZAMUDIO, M. FLORENCIO, P. GARCÍA-MURILLO, C. GÓMEZ-RODRÍGUEZ, A. PORTHEAULT, L. SERRANO \& P. SILJESTRÖM. 2010. Temporay ponds from Doñana National Park: a system of natural habitats for the preservation of aquatic flora and fauna. Limnetica, 29: 41-58.

DODSON, S. 1992. Predicting Crustacean Zooplankton Species Richness. Limnology and Oceanography, 37: 848-856.

DRINAN, T. J., G. N. FOSTER, B. H. NELSON, J. O'HALLORAN \& S. S. C. HARRISON. 2013. 
Macroinvertebrate assemblages of peatland lakes: Assessment of conservation value with respect to anthropogenic land-cover change. Biological Conservation, 158: 175-187.

FLORENCIO, M., L. SERRANO, C. GÓMEZ-RODRÍGUEZ, A. MILLÁN \& C. DÍAZ-PANIAGUA. 2009. Inter- and intra-annual variations of macroinvertebrate assemblages are related to the hydroperiod in Mediterranean temporary ponds. Hydrobiologia, 634: 167-183.

FLORÍN, M., C. MONTES \& F. RUEDA. 1993. Origin, hydrologic functioning, and morphometric characteristics of small, shallow, semiarid lakes (Lagunas) in La Mancha, central Spain. Wetlands, 13: 247-259.

GAN, D., S. I. KOTOB \& D. S. WALIA. 2007. Evaluation of a spectrophotometric method for practical and cost effective quantification of fulvic acid. Annals of Environmental Science, 1: 11-15.

GASCÓN, S., M. MACHADO, J. SALA, L. CANCELA DA FONSECA, M. CRISTO \& D. BOIX. 2012. Spatial characteristics and species niche attributes modulate the response by aquatic passive dispersers to habitat degradation. Marine and Freshwater Research, 63: 232.

GRASSHOFF, K., M. EHRHARDT \& K. KREMLING. 1983. Methods of seawater analysis. Verlag Chemie. Weinheim.

GRILLAS, P., P. GAUTHIER, N. YAVERCOVSKI \& C. PERENNOU. 2004. Mediterranean temporary pools: Issues relating to conservation, functioning and management. Station biologique de la Tour du Valat, Arles.

HAMILTON IV, R., P. S. KOURTEV, C. POST, J. DILLARD, K. J. KNEPPER \& R. COWART. 2012. Physicochemical Characteristics and Benthic Macroinvertebrate Communities in Temporary Surface Waters of Northern Stark County, Ohio. The Open Entomology Journal, 6: 1-12.

HAUTALA, K., J. PEURAVUORI \& K. PIHLAJA. 2000. Measurement of aquatic humus content by spectroscopic analyses. Water research, 34: 246258.

HAYASHI, M. \& G. VAN DER KAMP. 2007. Water level changes in ponds and lakes: the hydrological processes. In: Plant disturbance ecology: the process and the response. (Eds E.A. Johnson \& K. Miyanishi): pp. 311-339. Elsevier.

LI, W. \& M. H. H. STEVENS. 2010. How enrichment, ecosystem size, and their effects on species richness co-determine the stability of microcosm communities. Oikos, 119: 686-695.

MCHUGH, P. A., A. R. MCINTOSH \& P. G. JELLYMAN. 2010. Dual influences of ecosystem size and disturbance on food chain length in streams. Ecology Letters, 13: 881-890.

MICHELS, E. C., K. NEYS \& L. DEMEESTER. 2001. Zooplankton on the move: first results on the quantification of dispersal in a set of interconnected ponds. Hydrobiologia, 442: 117-126.

MOKANY, A., J. T. WOOD \& S. A. CUNNINGHAM. 2008. Effect of shade and shading history on species abundances and ecosystem processes in temporary ponds. Freshwater Biology, 53: 19171928.

NÕGES, T. 2009. Relationships between morphometry, geographic location and water quality parameters of European lakes. Hydrobiologia, 633: 3343.

O’NEILL, B. J. \& J. H. THORP. 2014. Untangling food-web structure in an ephemeral ecosystem. Freshwater Biology: n/a-n/a.

OERTLI, B., D. AUDERSET JOYE, E. CASTELLA, R. JUGE, D. CAMBIN \& J. B. LACHAVANNE. 2002. Does size matter? The relationship between pond area and biodiversity. Biological Conservation, 104: 59-70.

PALIK, B., D. BATZER, R. BUECH, D. NICHOLS, K. CEASE, L. EGELAND \& D. STREBLOW. 2001. Seasonal pond characteristics across a chronosequence of adjacent forest ages in northern Minnesota, USA. Wetlands, 21: 532-542.

POST, D. M. 2002. The long and short of food-chain length. Trends in Ecology \& Evolution, 17: 269277.

POST, D. M., M. L. PACE \& N. G. HAIRSTON. 2000. Ecosystem size determines food-chain length in lakes. Nature, 405: 1047-1049.

PTACNIK, R., T. ANDERSEN \& T. TAMMINEN. 2010. Performance of the Redfield Ratio and a Family of Nutrient Limitation Indicators as Thresholds for Phytoplankton N vs. P Limitation. Ecosystems, 13: 1201-1214.

R DEVELOPMENT CORE TEAM. 2015. R: a language and environment for statistical computing. R Foundation for Statistical Computing, Vienna.

ROMO, S., M. J. VILLENA \& A. GARCÍA-MURCIA. 2007. Epiphyton, phytoplankton and macrophyte ecology in a shallow lake under in situ experimental conditions Fundamental and Applied Limnology/Archiv für Hydrobiologie, 170: 197-209. 
ROSENZWEIG, M. L. 1995. Species Diversity in Space and Time. Cambridge University Press.

RUHÍ, A., D. BOIX, J. SALA, S. GASCÓN \& X. D. QUINTANA. 2009. Spatial and temporal patterns of pioneer macrofauna in recently created ponds: taxonomic and functional approaches. Hydrobiologia, 634: 137-151.

RUIZ, E. 2008. Management of Natura 2000 habitats. In: $3170 *$ Mediterranean temporary ponds. European Commission.

SALA, J., S. GASCÓN, D. BOIX, J. GESTI \& X. D. QUINTANA. 2004. Proposal of a rapid methodology to assess the conservation status of Mediterranean wetlands and its application in Catalunya (NE Iberian Peninsula). Archives des Sciences, 57: 141-151.

SCHRIEVER, T. A. \& D. D. WILLIAMS. 2013. Influence of pond hydroperiod, size, and community richness on food-chain length. Freshwater Science, 32: 964-975.

SIM, L. L., J. A. DAVIS, K. STREHLOW, M. MCGUIRE, K. M. TRAYLER, S. WILD, P. J. PAPAS \& J. O'CONNOR. 2013. The influence of changing hydroregime on the invertebrate communities of temporary seasonal wetlands. Freshwater Science, 32: 327-342.

SØNDERGAARD, M., E. JEPPESEN \& J. P. JEN-
SEN. 2005. Pond or lake: does it make any difference? Archiv Fur Hydrobiologie, 162: 143-165.

TAVERNINI, S., R. PRIMICERIO \& G. ROSSETTI. 2009. Zooplankton assembly in mountain lentic waters is primarily driven by local processes. Acta Oecologica, 35: 22-31.

VANSCHOENWINKEL, B., A. HULSMANS, E. DE ROECK, C. DE VRIES, M. SEAMAN \& L. BRENDONCK. 2009. Community structure in temporary freshwater pools: disentangling the effects of habitat size and hydroregime. Freshwater Biology, 54: 1487-1500.

VILLENA, M. J. \& S. ROMO. 2007. Effects of nutrients, fish, charophytes and algal sediment recruitment on the phytoplankton ecology of a shallow lake. International Review of Hydrobiology, 92: 626-639.

WALSH, C. \& R. MAC NALLY. 2013. hier.part: Hierarchical Partitioning. p. R package. R Foundation for Statistical Computing.

WILLIAMS, D. D. 2006. The biology of temporary waters. Oxford University Press. Oxford.

ZAPATA, M., F. RODRÍGUEZ \& J. L. GARRIDO. 2000. Separation of chlorophylls and carotenoids from marine phytoplankton: a new HPLC method using a reversed phase $\mathrm{C} 8$ column and pyridinecontaining mobile phases. Marine Ecology Progress Series, 195: 29-45. 